Economics Development Analysis Journal

\title{
Analisis Potensi Ekspor Hasil Pertanian Tanaman Pangan di Kabupaten Pati
}

\author{
Magdalena Sitindaon ${ }^{凶}$
}

Jurusan Ekonomi Pembangunan, Fakultas Ekonomi, Universitas Negeri Semarang

\section{Info Artikel}

\section{Sejarah Artikel:}

Diterima Oktober 2016

Disetujui Desember 2017

Dipublikasikan Februari 2017

Keywords:

Agriculture, Food Plants,

Location Quotient (LQ)

\begin{abstract}
Abstrak
Kabupaten Pati merupakan salah satu daerah di Jawa Tengah yang memiliki potensi besar dalam bidang pertanian. Slogan Pati Bumi Mina Tani sangat tepat diberikan untuk daerah ini mengingat banyaknya komoditi pertaniannya yang menjadi andalan seperti misalnya padi, ketela pohon, pisang, kacang hijau, semangka, tebu, kelapa kopyor, kopi, cengkeh, perikanan laut dan masih banyak lagi. Bahkan tidak sedikit dari komoditi tersebut yang berkualitas ekspor. Penelitian ini bertujuan untuk mengetahui bagaimana pertumbuhan tanaman pangan di Kabupaten Pati dan menganalisis potensi ekspor hasil pertanian tanaman pangan yang ada di Kabupaten Pati. Data yang digunakan dalam penelitian ini adalah data sekunder yang diperoleh dari Badan Pusat statistik (BPS) Provinsi Jawa Tengah dan Kabupaten Pati, Dinas Perindustrian dan Perdagangan, jurnal serta literature yang berkaitan dengan penelitian ini. Metode analisis yang digunakan yaitu Analisis Deskriptif, laju pertumbuhan dan Analisis Location Quotient (LQ).Hasil penelitian ini menunjukkan bahwa komoditi pertanian tanaman pangan di Kabupaten Pati yang berpotensi ekspor yaitu tanaman ubi kayu dan kacang hijau. Saran yang dapat diberikan dari penelitian ini adalah Pemerintah Kabupaten Pati sebaiknya memberi perhatian secara khusus dalam pengembangan sistem pertanian dalam memproduksi komoditi yang memiliki potensi untuk diekspor sehingga dapat meningkatkan pendapatan daerah dan masyarakat dan mencari pasar untuk memasarkan hasil-hasil pertanian Kabupaten Pati.
\end{abstract}

\section{Abstract}

Pati regency is one area in Central Java, which has great potential in agriculture. Pati slogan Earth Mina Tani very appropriate given for this area considering the number of agricultural commodities are a mainstay such as rice, cassava, bananas, green beans, watermelon, sugarcane, coconut kopyor, coffee, cloves, sea fishing and much more. Not even a hint of the quality commodity exports. This study aims to find out how to grow food in Pati Regency and analyze the potential export of agricultural crops in Pati regency. The data used in this research is secondary data obtained from the Central Bureau of statistics (BPS) and the District of Central Java Pati, Department of Industry and Trade, journals and literature associated with the study. The analytical method used is descriptive analysis, the rate of growth and Analysis of Location Quotient (LQ) The results of this study indicate that agricultural commodity crops in Pati regency are potential export of cassava and green beans. Advice can be given from this research is Pati regency government should give special attention to the development of agricultural systems in producing commodities that have the potential to be exported so that it can increase the income of the area and the community and looking for markets to sell agricultural products Pati regency.

(C) 2017 Universitas Negeri Semarang

\footnotetext{
凶Alamat korespondensi:

Ruang Jurnal Gedung L FE UNNES, Sekaran Gunungpati

Semarang, 50229, Indonesia

E-mail: magdalenatindaon@yahoo.com
} ISSN 2252-6965 


\section{PENDAHULUAN}

Sektor pertanian merupakan sektor yang berperan penting dalam perekonomian nasional terutama dalam sumbangannya terhadap PDB, penyediaan pangan penduduk dan bahan baku bagi industri, penyediaan lapangan pekerjaan, peningkatan pendapatan masyarakat dan pemantapan ketahanan pangan nasional, serta penyumbang devisa melalui ekspor dan sebagainya. Sebagai negara agraris, sektor pertanian menjadi sektor yang penting di Indonesia, hal ini dapat dilihat dari mayoritas penduduknya yang tinggal di daerah pertanian dan berprofesi sebagai petani. Berdasarkan data Badan Pusat Statistik (BPS) tahun 2014 sektor pertanian menyerap tenaga kerja sebanyak 4,92 juta jiwa atau sebesar 39,90 persen.

Seiring dengan perkembangan zaman telah terjadi peningkatan pengalihan sektor pertanian ke sektor industri, pendirian perusahaan atau perluasan pemukiman penduduk pada setiap negara sehingga terjadi penyempitan lahan dalam sektor pertanian. Besarnya tingkat pengalihan lahan pertanian menyebabkan kekurangan terhadap ketersediaan pangan. Keadaan yang demikian menjadi peluang besar bagi negara agraris untuk memasarkan hasil pertaniannya ke pasar internasional baik dalam bentuk primer maupun dalam bentuk turunan pertanian. Kehadiran pasar ekspor ini menjadi peluang besar bagi petani yang terkait langsung dengan produksi hasil pertanian untuk meraih pasar yang lebih luas dan meningkatkan pendapatan petani.

Salah satu indikator penting dalam perekonomian Nasional adalah ekspor. Indonesia sebagai negara yang kaya akan sumber daya alam memiliki potensi yang besar untuk menjadi salah satu negara pengekspor terbesar dalam berbagai kategori migas dan nonmigas. Akan tetapi beberapa tahun terakhir ekspor Indonesia cenderung mengalami penurunan. Berdasarkan data dari Badan Pusat Statistik (BPS) tahun 2013 nilai ekspor migas mengalami penurunan yang drastis yaitu $8,63 \%$ pada Mei 2013. Turun hampir 100\% jika dibandingkan dengan penurunan pada Juni 2012 yang hanya mencapai $4,54 \%$. Hal yang sama juga terjadi pada sektor nonmigas. Nilai ekspor nonmigas mencapai angka 9,26\% pada Mei 2013 dan 4,44\% pada Juni 2012. Meskipun mengalami penurunan, kedua sektor ini tetap memberikan kontribusi yang cukup besar bagi perekonomian Indonesia seperti halnya dalam sektor pertanian.

Melihat pentingnya sektor pertanian dalam pertumbuhan ekonomi, tiap - tiap daerah meningkatkan pembangunan di sektor ini seperti halnya di Kabupaten Pati. Sektor ini merupakan penyumbang terbesar terhadap PDRB Kabupaten Pati hingga saat ini. Hal tersebut dapat dipahami karena kondisi wilayah Kabupaten Pati yang sangat cocok untuk melakukan kegiatan pertanian. Adapun jenis tanaman yang dibudidayakan di Kabupaten Pati ini adalah jenis umbi- umbian, sayur- sayuran, buah- buahan dan tanaman padi.

Kabupaten Pati merupakan salah satu daerah di Jawa Tengah yang memiliki potensi besar dalam bidang pertanian. Slogan Pati Bumi Mina Tani sangat tepat diberikan untuk daerah ini mengingat banyaknya komoditi pertaniannya yang menjadi andalan seperti misalnya padi, ketela pohon, pisang, kacang hijau, semangka, tebu, kelapa kopyor, kopi, cengkeh, perikanan laut dan masih banyak lagi. Bahkan tidak sedikit dari komoditi tersebut yang berkualitas ekspor.

Komoditi pertanian Kabupaten Pati yang paling banyak dibudidayakan adalah tanaman pangan. Tanaman pangan meliputi kelompok biji - bijian, kacang- kacangan, umbi- umbian seperti kacang tanah, kacang hijau, jagung, kedelai, padi, ubi kayu, dan ubi jalar. Tanaman pangan sampai saat ini masih memegang peranan penting sebagai pemasok kebutuhan konsumsi penduduk. Khusus di Indonesia, tanaman pangan juga berkedudukan strategis dalam memelihara stabilitas ekonomi. Bahan pangan, terutama padi masih menjadi salah satu komoditas kunci. Tanaman pangan Kabupaten Pati dikembangkan tidak hanya untuk pemenuhan kebutuhan penduduknya saja tetapi juga untuk pemenuhan bahan baku industri daerah. Kabupaten Pati juga memiliki hasilhasil pertanian yang kualitas dan kuantitasnya layak diperhitungkan disamping peluang ekspor. 
Hal ini menjadi keuntungan besar bagi kabupaten Pati. Dengan begitu, kabupaten Pati bisa lebih memaksimalkan peluang dan potensi yang ada dalam pengembangan ekspor pertanian daerahnya.

Adapun tujuan dari penelitian ini yang hendak dicapai oleh penulis dalam penelitian ini adalah: (1) Untuk mengetahui besarnya komoditi hasil pertanian tanaman pangan di Kabupaten Pati. (2) Untuk menganalisis dan mengetahui besarnya potensi ekspor komoditi hasil pertanian tanaman pangan di Kabupaten Pati.

\section{METODE PENELITIAN}

Metode analisis yang digunakan dalam penelitian ini adalah metode Location Quotient, dengan menggunakan rumus:

Rumus Location Quotient (LQ) adalah sebagai berikut:

$$
\mathrm{LQ}=\frac{v i / v t}{V i / v t}
$$

Sumber: Nur Indah Wulandari, 2010

Dimana:

LQ = koefisien Location Quotient

vi = jumlah produksi komoditi i di kabupaten Pati

vt $\quad=$ jumlah produski seluruh komoditi pertanian di Kabupaten Pati
$\mathrm{Vi}=$ jumlah produksi komoditi i di Jawa Tengah

$\mathrm{Vt}=$ jumlah produksi selueuh komoditi pertanian di Jawa Tengah

Selain menggunakan metode analisis Location Quotient, penelitian ini juga menggunakan rumus menghitung pertumbuhan komoditi pertanian untuk mngetahui tingkat pertumbuhan hasil- hasil petanian dari masingmasing komoditi pertanian di Kabuapten Pati.

Adapun rumusnya:

$$
r_{i k}=\frac{P_{i k t-P_{i k 0}}}{P_{i k 0}} \times 100 \%
$$

Sumber : Nur Indah Wulandari, 2010

Dimana:

Tik = Laju pertumbuhan nilai produksi komoditi di tingkat kabupaten

Pikt =Nilai produksi tingkat kabupaten pata tahun ke $\mathrm{t}$

Piko =Nilai produksi komoditi tingkat kabupaten pada awal tahun.

\section{HASIL DAN PEMBAHASAN}

\section{Pertumbuhan Hasil Komoditi Pertanian Tanaman Pangan di Kabupaten Pati}

Perhitungan pertumbuhan komoditi tanaman pangan dilakukakan untuk mengetahui tingkat pertumbuhan dari masing- masing komoditi pertanian tanaman pangan yang ada di Kabupaten Pati

Tabel 1. Hasil Perhitungan Pertumbuhan Komoditi Tanaman Pangan di Kabupaten Pati Tahun

\begin{tabular}{|c|c|c|c|c|c|c|c|}
\hline \multirow[t]{2}{*}{ Komoditi } & \multicolumn{6}{|l|}{ Tahun } & \multirow[t]{2}{*}{ Rata-rata } \\
\hline & 2009 & 2010 & 2011 & 2012 & 2013 & 2014 & \\
\hline Jagung & 97210 & 124969 & 113491 & 119123 & 96028 & 126411 & 116004 \\
\hline$\%$ & & $28 \%$ & $-9 \%$ & $4.72 \%$ & $-24 \%$ & $31.63 \%$ & $6.27 \%$ \\
\hline Kedelai & 3988 & 2982 & 3335 & 2764 & 3988 & 3058 & 3225 \\
\hline$\%$ & & $-25 \%$ & $11.83 \%$ & $17.12 \%$ & $44.28 \%$ & $-23.3 \%$ & $-1.86 \%$ \\
\hline Kacang tanah & 3776 & 4176 & 3359 & 4703 & 3342 & 4584 & 4032 \\
\hline$\%$ & & $11 \%$ & $-20 \%$ & $40 \%$ & $-27 \%$ & $34 \%$ & $7.85 \%$ \\
\hline Padi & 528036 & 609505 & 524732 & 575906 & 584270 & 497071 & 558296 \\
\hline$\%$ & & $15 \%$ & $-14 \%$ & $10 \%$ & $1 \%$ & $-15 \%$ & $-0.61 \%$ \\
\hline Kacang Hijau & 16066 & 15180 & 15240 & 16213 & 12510 & 12748 & 14378 \\
\hline$\%$ & & $-6 \%$ & $0 \%$ & $6 \%$ & $-23 \%$ & $2 \%$ & $-3.93 \%$ \\
\hline Ubi kayu & 386434 & 643558 & 538338 & 732961 & 698325 & 744746 & 671585 \\
\hline$\%$ & & $67 \%$ & $-16 \%$ & $36 \%$ & $-5 \%$ & $7 \%$ & $17.63 \%$ \\
\hline Ubi Jalar & 4115 & 2463 & 1860 & 2690 & 1184 & 2122 & 2063 \\
\hline$\%$ & & $-40 \%$ & $-24 \%$ & $45 \%$ & $-56 \%$ & $79 \%$ & $0.65 \%$ \\
\hline
\end{tabular}
2010-2014

Sumber: Data sekunder diolah. 
Berdasarkan tabel diatas menunjukkan bahwa ada 7 hasil pertanian yang terdapat di Kabupaten Pati yaitu, Jagung, Kedelai, Kacang Tanah, Padi, Kacang Hijau, Ubi Kayu, Ubi Jalar. Dari masing-masing hasil pertanian tersebut dapat dilihat dari tiap tahun mengalami perubahan yang fluktuatif. Berdasarkan hasil penelitian terlihat bahwa rata-rata untuk hasil pertanian jagung mengalami peningkatan sebesar 6,275. Komoditi kedelai mengalami penurunan $1.84 \%$, Kacang Tanah mengalami peningkatan sebesar $7.85 \%$, Padi mengalami penurunan $0.61 \%$, Kacang Hijau mengalami penurunan sebesar $3.93 \%$, Ubi Kayu mengalami peningkatan sebesar 17.63\%, Ubi Jalar mengalami peningkatan sebesar $0.65 \%$ dari tiap tahun-nya di periode 2010 -2014. Berdasarkan hal tersebut dapat dilihat bahwa yang mengalami peningkatan terbesar dari hasil pertanian adalah pada jenis tanaman jagung, kacang tanah, ubi kayu, padi, dan tanaman ubi jalar.

\section{Potensi Ekspor Hasil Pertanian Tanaman Pangan di Kabupaten Pati}

Pada penjelasan sebelumnya telah dibahas mengenai peranan dan kontribusi sektor pertanian dalam mendukung perekonomian Kabupaten Pati. Analisis Location Quation merupakan perbandingan besarnya peranan suatu sektor/industri di suatu daerah terhadap peranan suatu sektor/industri tersebut secara nasional atau di suatu kabupaten terhadap peranan suatu sektor/industri secara regional/ provinsi.

Jumlah produksi yang besar di Kabupaten Pati bukan merupakan faktor utama menjadi komoditi basis apabila hasil LQ nya menunjukkan nilai kurang dari satu. Dengan menggunakan metode ini dapat diketahui komoditi-komoditi mana saja yang berpotensi ekspor.

Apabila koefisien LQ $>1$ berarti komoditi tersebut menjadi komoditi basis di Kabupaten Pati, hasilnya tidak saja untuk memenuhi kebutuhan wilayah bersangkutan, tetapi juga dapat diekspor ke wilayah lain.

Bila LQ $<1$, berarti komoditi tersebut termasuk komoditi non basis, yang berarti komoditi tersebut tidak dapat memenuhi kebutuhan wilayahnya sendiri sehingga perlu impor dari wilayah lain. Bila LQ $=1$, berarti komoditi tersebut hanya mampu memenuhi kebutuhan wilayah sendiri dan tidak mampu untuk dieskpor.

Tabel 2. Hasil Perhitungan Location Quotient (LQ) Hasil Pertanian Kabupaten Pati Tahun 2010-2014

\begin{tabular}{cccccccc}
\hline Tahun & Jagung & Kedelai & $\begin{array}{c}\text { Kacang } \\
\text { Tanah }\end{array}$ & Padi & $\begin{array}{c}\text { Kacang } \\
\text { Hijau }\end{array}$ & $\begin{array}{c}\text { Ubi } \\
\text { Kayu }\end{array}$ & $\begin{array}{c}\text { Ubi } \\
\text { Jalar }\end{array}$ \\
\hline 2010 & 0.51 & 0.19 & 0.32 & 0.75 & 2.44 & 2.08 & 0.22 \\
2011 & 0.55 & 0.40 & 0.37 & 0.75 & 1.76 & 2.07 & 0.15 \\
2012 & 0.47 & 0.22 & 0.39 & 0.68 & 1.76 & 2.31 & 0.19 \\
2013 & 0.41 & 0.51 & 0.34 & 0.71 & 2.48 & 2.17 & 0.08 \\
2014 & 0.51 & 0.30 & 0.47 & 0.63 & 1.63 & 2.31 & 0 \\
Rata- & & & & & & & .14 \\
Rata & 0.49 & 0.32 & 0.38 & 0.71 & 2.01 & 2.19 & \\
\hline
\end{tabular}

Sumber: data sekunder diolah 
Pada tabel diatas dapat dilihat hasil dari nilai Location Quotient hasil pertanian di Kabupaten Pati tahun 2010-2014, terdapat hasil pertanian yang memiliki nilai paling tinggi yaitu tanaman kacang hijau dan ubi kayu dengan nilai masing masing LQ sebesar 2.01 dan 2.19.

\section{a. Jagung}

Jagung merupakan komoditas pangan sumber karbohidrat kedua setelah beras. Sebagian besar penduduk Indonesia menggunakan jagung sebagai pangan pokok. Selain sebagai sumber karbohidrat, jagung juga ditanam sebagai pakan ternak, diambil minyaknya, dibuat tepung, dan untuk bahan baku industri. Berdasarkan nilai indeks Location Quotient (LQ) pada tabel diatas diketahui bahwa LQ komoditi jagung lebih kecil dari 1 yaitu sebesar 0.49 yang artinya Kabupaten Pati perlu pasokan jagung dari luar daerah untuk memenuhi kebutuhan jagung di Kabupaten pati.

Pada tahun 2014 luas panen jagung di Kabupaten Pati seluas 20.751 Ha dan mengalami peningkatan sebesar $3.529 \mathrm{Ha}$ dari tahun sebelumnya. Dengan luas panen 20.751 Ha Kabupaten Pati mampu menghasilkan jagung sebanyak 126.411 ton pada tahun 2014 dan sebesar 96.028 ton pada tahun 2013. Daerah penghasil jagung di Kabupaten Pati adalah Sukolilo, kayen, tambakromo, Winong, Pucakwangi, Batangan, Gembong, Margorejo, Gunung wungkal, Tlogowungu dan trangkil.

\section{b. Kedelai}

Kedelai atau kacang kedelai adalah salah satu tanaman polong-polongan yang menjadi bahan dasar banyak makanan seperti kecap, tahu dan tempe. Berdasarkan indeks Location Quotient (LQ) pada tabel diatas kedelai termasuk ke golongan komoditi non basis karena memiliki nilai $\mathrm{LQ}<1$ yaitu sebesar 0,32 yang artinya komoditi kedelai Kabupaten Pati belum cukup untuk memenuhi kebutuhan lokal sehingga perlu dilakukan impor.Dilihat dari perkembangan produksinya, kedelai mengalami penurunan. Pada tahun 2013 kedelai mampu diproduksi sebesar 3.988 ton, dan mengalami penurunan pada tahun 2014 sebesar 3.058 ton. Daerah penghasil kedelai di Kabupaten Pati adalah Sukolilo, Kayen, Tambakromo, Winong, Jakenan, Pati, Gabus, dan Margorejo.

\section{c. Kacang Tanah}

Kacang tanah atau yang memiliki nama ilmiah Arachis hypogeae L adalah salah satu tanaman polong-polongan yang banyak di budidayakan di Indonesia. Tanaman kacang tanah sendiri merupakan tanaman semak dengan tinggi sekitar $30 \mathrm{~cm}$. Berdasarkan nilai indeks Location Quotient (LQ) pada tabel diatas diketahui bahwa LQ komoditi kacang tanah lebih kecil dari 1 yaitu sebesar 0.38 yang artinya Kabupaten Pati perlu pasokan kentang dari luar daerah untuk memenuhi kebutuhan kacang tanah di Kabupaten Pati. Tetapi faktanya meskipun nilai LQ komoditi kacang tanah lebih kecil dari satu, Kabupaten Pati mampu melakukan ekspor kacang tanah setiap tahunnya. Yang menjadi daerah pemasaran kacang tanah di luar negeri adalah Malaysia dan Singapura. Perusahaan yang menjadi eksportir komoditi kentang adalah PT.garuda Food PP Jaya, CV.Mojo Agung, PT.Gunanusa Era Mandiri dan Fa.Sinar Jaya.

\section{d. Kacang Hijau}

Kacang hijau adalah sejenis palawija yang dikenal luas di daerah tropika. Tumbuhan yang btermasuk suku polong-polongan ini memiliki banyak manfaat dalam kehidupan sehari-hari sebagai sumber bahan pangan berprotein nabati tinggi.Dari tabel diatas dapat diketahui bahwa kacang hijau merupakan komoditi pertanian kabupaten Pati yang memiliki nilai LQ > 1 yaitu sebesar 2.01 yang artinya kacang hijau termasuk komoditi basis atau memiliki potensi ekspor karena produksinya melebihi kebutuhan lokal. Luas panen kacang hijau di Kabupaten Pati seluas $11.300 \mathrm{Ha}$ pada tahun 2014 dan mengalami peningkatan seluas $943 \mathrm{Ha}$ dari tahun sebelumnya. Dengan luas panen $11.340 \mathrm{Ha}$ pada tahun 2014 Kabupaten Pati mampu menghasilkan kacang tanah sebesar 12.748 ton atau mengalami peningkatan sebesar 238 ton dari tahun sebelumnya. Daerah penghasil kacang hijau di Kabupaten PatiSukoliko, Kayen, Tambakromo, Winong, Pucakwangi, 
Jaken, batangan, Juwana, Pati, Gabus, dan Margorejo.

\section{e. Padi}

Dari sekian banyak sumber karbohidrat, padi ternyata merupakan pangan yang ideal bagi kita. Itulah sebabnya padi menjadi sangat penting bagi bangsa Indonesia. Dari indeks Location Quotient (LQ) pada tabel diatas diketahui bahwa tanaman padi memiliki nilai $\mathrm{LQ}<1$ yaitu sebesar 0,71 yang artinya tanaman padi bukan komoditi golongan basis sehingga tidak bisa dilakukan ekspor karena produksi lokal akan bawang merah belum mampu memenuhi kebutuhan daerah sendiri.

\section{f. Ubi Kayu}

Ubi kayu atau ketela pohon adalah salah satu komoditas pertanian jenis umbi-umbian yang cukup penting di Indonesia baik sebagai sumber pangan maupun sumber pakan. Berdasarkan tabel diatas diketahui bahwa ubi kayu merupakan komoditi basis karena memiliki nilai LQ>1 yaitu sebesar 2.19 yang artinya ubi kayu juga salah satu komoditi yang telah mampu memenuhi kebutuhan lokal dan dapat melakukan ekspor. Luas panen ubi kayu pada tahun 2014 seluas 17.871 ha, mengalami peningkatan seluas $1.708 \mathrm{Ha}$ dari tahun sebelumnya. Dengan luas panen $17.871 \mathrm{Ha}$ Kabupaten Pati mampu menghasilkan 744.746 Ton ubi kayu dan mengalami peningkatan produksi sebesar 46.421 Ton. Hampir semua kecamatan di Kabupaten Pati menghasilkan tanaman ubi kayu.

\section{g. Ubi jalar}

Ubi jalar (Lpomoea batatas) dikenal juga dengan ketela rambat adalah umbi-umbian yang memiliki kadar gizi (karbohidrat) yang tinggi.Dari tabel diatas diketahui bahwa ubi jalar memiliki nilai LQ $<1$ yaitu sebesar 0,16 yang artinya ubi jalar tidak memiliki keunggulan komparatif sehingga komoditi ini tidak cukup untuk diekspor. Dengan nilai LQ lebih kecil dari satu maka Kabupaten Pati perlu melakukan impor untuk memenuhi kebutuhan akan ubi jalar. Berdasarkan hasil analisis di atas, terdapat temuan-temuan penting dalam penelitian ini. Hasil pertanian yang terdiri dari Jagung, Kedelai, Kacang Tanah, Padi, Kacang
Hijau, Ubi Kayu, Ubi Jalar. Dari ke tujuh hasil pertanian tersebut, kacang hijau dan ubi kayu memiliki nilai LQ yang lebih tinggi dibandingkan dengan hasil pertanian lainnya yaitu masing-masing sebesar 2,01 dan 2,19. Dari hal tersebut dapat dikatakan bahwa hasil pertanian kacang hijau dan ubi kayu masuk ke dalam sektor basis atau memiliki potensi ekspor karena produksinya melebihi kebutuhan lokal. Dengan demikian, hasil pertanian yaitu kacang hijau dan ubi kayu menjadi salah satu komoditi yang patut untuk dikelola dan dikembangkan untuk memajukan perekononomian di Kabupaten Pati.

Demi mempertahankan kebasisan tanaman kacang hijau dan ubi kayu di dalam potensi ekspor hasil pertanian di Kabupaten Pati, pemerintah daerah hendaknya memberikan perhatian kepada para petani ubi kayu dan kacang hijau dengan cara memberikan penyuluhan pertanian, sarana pertanian secara gratis dan kredit dengan bunga rendah, sehingga petani ubi kayu dan kacang hijau bisa dengan mudah mengelola dan mengembangkannya.

\section{SIMPULAN}

Dari hasil analisis yang dilakukan dalam penelitian ini, maka dapat di tarik kesimpulan antara lain sebagai beikut: (1) Berdasarkan hasil perhitungan pertumbuhan hasil komoditi pertanian tanaman pangan, komoditas yang paling berkembang di Kabupaten Pati adalah tanaman ubi kayu, kacang tanah, jagung dan ubi jalar. (2) Berdasarkan hasil perhitungan alat analisis Location Quotient (LQ) pada subsektor tanaman pangan, jenis komoditas pertanian yang memiliki potensi ekspor yang tinggi yaitu kacang hijau dan ubi kayu.

Dari beberapa kesimpulan di atas, maka dapat diberikan sejumlah saran sebagai berikut: (1) Pemerintah Kabupaten Pati sebaiknya memberikan penyuluhan pertanian dalam mengatasi segala permasalahan pertanian yang ada sehingga komoditi tanaman pangan di Kabupaten Pati berkembang dengan baik. (2) Untuk masyarakat di Kabupaten Pati agar mengembangkan komoditas pertanian yang berpotensi ekspor seperti ubi kayu dan kacang 
hijau dengan penggunaan bibit unggul, sistem pertanian modern dan penggunaan alat pertanian modern.

\section{DAFTAR PUSTAKA}

Abolagba, E. O., Onyekwere, N. C., et. al (2010). Determinants of Agricultural Exports. Journal of Human Ecology Vol. 29 (3) pp. 181-184.

Adisamita, Rahardjo. 2005. Dasar- dasar Ekonomi Wilayah. Yogyakarta: Graha Ilmu

Badan Pusat Statistik, 2010. Pati Dalam Angka 2010

----, 2013. Pati Dalam Angka 2013

----, 2015. Pati Dalam Angka 2015

Bukit, Ita Marlina. 2013. Analisis Potensi Ekspor Hasilhasil Pertanian di Kabupaten Karo. Jurnal Ekonomi dan Keuangan. Vol 1, No 5. Diunduh dari http://jurnal.usu.ac.id/index.php/edk/article /view/9216 (Diakses 30 Maret 2015)

Daniel, Moehar. 2004. Pengantar Ekonomi Pertanian. Medan: PT Bumi Aksara

Diao, Xinshen., Hazell, Peter., Thurlow, James. 2010. The Role of Agriculture in African Development. World Development. Vol. 38 (10) pp. 1375-1383.

Hamonangan, Luhut. 2009. Prospek Pembangunan Sektor Pertanian di Kabupaten Karo. Skripsi. Medan: fakultas Ekonomi USU

Husni, A. Malian, 2003. Faktor- Faktor Yang Mempengaruhi Ekspor Produk Pertanian dan Produk Imdustri Pertanian Indonesia : Pendekatan
Macroeconometric Models dengan Path Analysis. Dalam Jurnal Agro Ekonomi, Volume 21 No 2.

Kurniawan, Rony. 2014. Aplikasi Location Quotient (LQ) Sebagai Metode Penentuan Komoditas Palawija Unggulan di Kabupaten Nganjuk. Jurnal Riset Ekonomi dan Bisnis, Vol 1 No 2.

Melissa, Yuwanti. 2003. Analisis Ekspor Sayur- Mayur Sumatera Utara dan Permasalahannya. Skripsi. Medan: Fakultas Ekonomi USU

Mubyarto. 1972. Pengantar Ekonomi Pertanian. Jakarta: LP3ES

Neumann, Kathleen., Verburg, Peter H. et al. (2010). The yield gap of global grain production: A spatial analysis. Agriculture System Vol. 103 (5) pp. 316-326.

Rahardjo, M.D. 1986. Transformasi Pertanian, Industrialisasi dan Kesempatan Kerja. Jakarta: UI PRESS

Soekartawi. 1995. Pembangunan Pertanian. Jakarta: PT Raja Grafindo Persada

Tambunan, Tulus. 2001. Perekonomian Indonesia, Teori dan Temuan Empiris. Jakarta: Ghalia Indonesia

Tarigan, Robinson. 2009. Ekonomi Regional, Teori dan Aplikasi. Medan: PT Bumi Aksara

Todaro, M.P. 1994. Pembangunan Ekonomi di Dunia Ketiga. Jakarta: Erlangga

Wulandari, Nur Indah. 2010. Penentuan Agribisnis Unggulan Komoditi Pertanian Berdasarkan Nilai Produksi di Kabupaten Grobogan. Tesis. Sermarang: Fakultas Ekonomi UNDIP. 